\title{
STUDENTS' LEARNING CREATIVITY BY THE IMPLEMENTATION OF CONTEXTUAL-BASED LEARNING IN THE SUBJECT OF NATURAL SCIENCE
}

\author{
Fifi Faridah ${ }^{1}$, Salahudin $^{2}$, Mariamah $^{3}$, and Muhamad Ajwar ${ }^{4}$ \\ ${ }^{1}$ Program Studi Pendidikan Teknologi Informatika, STKIP Taman Siswa Bima, Bima, Indonesia \\ ${ }^{2}$ Program Studi Penjaskesrek, STKIP Taman Siswa Bima, Bima, Indonesia \\ ${ }^{3}$ Program Studi Pendidikan Matematika, STKIP Taman Siswa Bima, Bima, Indonesia \\ ${ }^{4}$ Program Studi Pendidikan Guru Sekolah Dasar, STKIP Taman Siswa Bima, Bima, Indonesia \\ *Email: mariamahmariamah85@yahoo.co.id
}

Accepted: November, 11 2021. Approved: November, 15 2021. Published: November, 222021

\begin{abstract}
One of the competencies needed by students in understanding science concepts is learning creativity. Reality shows that science learning in schools still experience various obstacles. One of which is the low learning creativity of students. The purpose of this study is to develop student learning creativity through contextual-based science learning. This study is an experimental study with a research sample consisting of two classes. The instrument used to measure students' learning creativity was an essay test. The data analysis used was t-test. The results of the analysis obtained a significant value (2-tailed) of 0.000 , in the value was less than 0.05 , so it is concluded that Ho is rejected or Ha is accepted, which interprets that the application of contextualbased learning can increase student learning creativity.
\end{abstract}

Keywords: Creativity, Science learning, Contextual

\section{INTRODUCTION}

Natural Science subject is one of the important subjects to learn in school, therefore, natural science is currently being taught starting from elementary school. The natural science learning at school carries important purposes in generating students with good qualifications, namely creative, critical thinker, logic, and problem solver in daily life. One of the competencies required to understand the concept of natural science is creativity of learning. On the other hand, reality shows that natural science learning in school still experiences many problems. According to the study [1], the most frequent problem found during the implementation is students' learning outcomes are not optimal. In addition, study [2] found that the less creative way of teachers' material presentation is mostly responsible to students' lack of attention during the learning process. Furthermore, [3] stated that the learning methods tend to be monotonous and teacher-centered leading to students' low creativity. [4] And [5] stated that most of students find natural science difficult. It is proved by the unsatisfying learning outcomes and students tend to be less creative, stuck to the books, and can't develop the ideas.

According to Putri \& Harto [6] that "creativity involves a set of attributes (like self confidence, desire for achievement, sensitivity) and thinking skills (like fluency, mental flexibility, imagination)". Therefore, creativity is a required skill to master the concept of Natural Science. [7] Stated that the learning process doesn't only require students to be active, but also to be creative. Creativity itself builds a supporting condition to the learning process, making it more interesting. [8] Stated that individual creativity can be measured by their capability in solving problems with new ideas of problem solving, freeing them from the monotonous way of thinking. [10] Stated that students' low creativity is responsible to their passive acting during the learning process. Based on what explained before, students experience a series of problems in Natural Science learning, on the other hand, creativity is highly required in the process of Natural Science learning, by that means, we need a solution to overcome the Natural Science learning problems in elementary school to be particular. One solution to be offered is applying various methods of learning by considering the content of the material being taught, this study offers contextual-based Natural Science learning. [11] Stated that the Natural Science learning is related to nature, therefore, the subject is suitable to be implemented contextually. [12] Stated the contextual-based learning is effective to be implemented in the learning process. A contextual learning gives students opportunity to directly take part in the process so that it can improve their potency to seek, save, and implement the concept they've learned [13].

[14] said that students' learning creativity is not only defined as the capability to create something new, but also to combine the ideas and implement them in a new view. (Nugraha, Kristin and Indri Anugraheni) said that creativity is related to capability creating something new based on the results of thinking process. Something new related to product which differs from the previous creation and has innovation value. [10] Defined creativity as students' capability to solve problems by indicating four indicators of thinking such as: 1) fluency (giving a 
number of answers); 2) flexibility (giving a variety of answers and point of views); 3) originality; and 4) elaboration. Operationally, creativity defined as the capability that indicates fluency, flexibility, and originality, also elaborating (developing, enriching, and detailing) an idea. Students' creativity showed by several indicators such as curiosity and providing a number of ideas [16]. According to Djudin [17], practicing students' creativity gives a significant contribution to flexibility and problem solving capabilities to experience the change later on.

\section{RESEARCH METHODS}

The study is a quasi-experimental research with a design study of two group pretest-posttest. The following Table 1 presents the design of the study.

Table 1. Study Design

\begin{tabular}{cccc}
\hline Class & Initial Test & Treatment & Final test \\
\hline Experiment & $\sqrt{ }$ & $\sqrt{ }$ & $\sqrt{ }$ \\
Control & $\sqrt{ }$ & - & $\sqrt{ }$ \\
\hline
\end{tabular}

Population and sample of the study was fourth grade students of SDN Talabiu. One class was used as experiment class and another one as control class.
The data collection was carried out by instruments in form of essay test with 5 questions. Test instrument was already passed the validity test by peer consultation. The indicators of students' creativity are presented in the following Table 2.

Table 2. Creativity Indicators in Learning Process

\begin{tabular}{|c|c|c|}
\hline No & Aspects & Creativity indicators \\
\hline 1 & Flexibility & $\begin{array}{l}>\text { Generating various ideas and answers } \\
>\text { Viewing a problem from many points of view } \\
>\text { Seeking many alternative ideas }\end{array}$ \\
\hline 2 & Originality & $\begin{array}{l}\text { Generating unique and fresh answers and ideas } \\
\text { Thinking uncommonly on how to state things } \\
\text { Having a strong will to finish things }\end{array}$ \\
\hline 3 & Elaboration & $\begin{array}{l}\text { Responding questions with desire, active, and spirit in finishing } \\
\text { tasks } \\
>\text { Daringly to accept and carry difficult tasks } \\
>\text { Critical in reviewing the results } \\
>\text { Asking questions aggressively }\end{array}$ \\
\hline 4 & Fluency & $>$ Providing many ideas, answers, and solvers to probems. \\
\hline
\end{tabular}

Hypothesis test of the study was carried out by t-test but undergoing the prerequisite tests first, namely normality tests using Chi Square Test and homogeneity tests. T-test was done at a significance level of $5 \%$ and $\mathrm{Ha}$ is accepted if $\mathrm{t}$ count is higher than $\mathrm{t}$ table. The following formula was used in the test.

$$
M e=\frac{\sum X_{i}}{n}
$$

\section{Description:}

$\begin{array}{ll}\text { Me } & =\text { Mean } \\ \sum \mathrm{x}_{\mathrm{i}} & =\text { Total score of all students } \\ \mathrm{n} & =\text { the number of students }\end{array}$

The next step was adjusting the category in the following interval category:
Table 3. Students' creativity category

\begin{tabular}{cc}
\hline Interval & Category \\
\hline $81-100$ & Very high \\
$61-80$ & High \\
$41-60$ & Quite high \\
$21-40$ & Low \\
$1-20$ & Very low \\
\hline
\end{tabular}

The data analysis was carried out by undergoing t-test to determine the effectiveness of the learning material. The following formula was used in the t-test.

$$
t=\frac{\bar{x}-\mu_{0}}{S E}=\frac{\bar{x}-\mu_{0}}{\frac{s}{\sqrt{n}}}
$$

\section{RESULTS AND DISCUSSION}

The following table will describe the study results about students' creativity after given the treatment of contextual-based learning. Based on the 
analysis using SPSS, the average score was 73.18 in the category of high. The highest score was 96 while the lowest was 52. The following Table 4 presents the data.

Before conducting the hypothesis test using t-test, the prerequisite test was carried out before. Normality test of the data was carried out using Kolmogrov-Smirnof test. A data is defined as normally distributed if the significance value is higher than 0.05 (sig. > 0.05). Based on the data analysis, the significance value was higher than 0.05 (0.902>
0.05). It can be concluded that the data was normally distributed. The following Table 5 presents the results of normality test using SPSS for the initial data test.

The data of control class was also normally distributed, the significance value was higher than $0.05(0.802>0.05)$. The next step was homogeneity tests for both classes. Based on the Box's M and Levene's test analysis, the significance value was lower than 0.05 , the data indicated that the students creativity data in the study was homogenous.

Table 4. Data description of Students' Creativity in Experiment Class

Descriptive Statistics

\begin{tabular}{|c|c|c|c|c|c|c|c|}
\hline & $\mathrm{N}$ & Range & Minimum & Maximum & Mean & Std. Deviation & Variance \\
\hline Creativity & 22 & 44.00 & 52.00 & 96.00 & 73.1818 & 11.94287 & 142.632 \\
\hline Valid N (listwise) & 22 & & & & & & \\
\hline
\end{tabular}

Table 5. The results of normality data test One-Sample Kolmogorov-Smirnov Test in Experiment Class

\begin{tabular}{llr}
\hline $\mathrm{N}$ & & Creativity \\
Normal Parameters $^{\mathrm{a}}$ & Mean & 22 \\
& Std. Deviation & 73.1818 \\
Most Extreme Differences & Absolute & 11.94287 \\
& Positive & .121 \\
& Negative & .121 \\
Kolmogorov-Smirnov Z & & -.118 \\
Asymp. Sig. (2-tailed) & & .569 \\
a. Test distribution is Normal. & .902 \\
\hline
\end{tabular}

Hypothesis test was carried out to determine the effectiveness of contextual-based learning implementation. The test criteria are as follows: if $t$ count is higher than $t$ table, Ho is rejected and if the other way around, Ho is accepted. If the significance value of 2-tailed is lower than 0.05 , Ho is rejected, the other way around, Ho is accepted. Based on the results of the data using SPSS, t count was 4.784 with a degree of freedom $(\mathrm{df}=42)$. Compared to $\mathrm{t}$ table, the value is 1.682 , if the significance value (2-tailed) obtained is lower than 0.05 , by that means, Ho is rejected and $\mathrm{Ha}$ is accepted. The results indicated that the implementation of contextual-based learning can improve students' creativity. The result of the study is in accordance with the previous studies, such as the study conducted by [3] and [18].

[12] Said that Natural Science is expected to be students' place to learn about themselves and the nature, as well as a potential prospect for further developments. Therefore, contextual-based learning is suitable for Natural Science learning. During the learning process, it provides opportunity for students to directly develop competencies by doing and implementing the concepts. The concepts of Natural Science are exist and implemented in everyday life, it also trains students to be a problem solver. [2] Stated that the model of Contextual Teaching and Learning (CTL) can improve students' creativity in learning. By that means, the method is also proved to improve students' creativity in learning.

The implementation of contextual-based learning in Natural Science can develop many aspects such as flexibility, originality, elaboration, and fluency. These aspects are the parts that shape an indicate students' creativity. Flexibility shows students' capability to provide ideas, answers, as well as questions. They can easily understand the learning material because they learn through their surroundings and what they have been experiencing in everyday life. According to [4], creative students can give various ideas and active in asking questions if they don't get what the teachers is delivering.

Originality is showed if students get all the tasks well finished by providing new ideas to the 
problems. According to [19], students' creativity can be developed by local-based learning models, one of which is contextual-based learning. Elaboration is indicated when students ask questions actively and full of spirits, to be short, their enthusiasm during the learning process. They can give examples according to what the teacher deliver and ask. According to Slameto [10], students' creativity can be shown by their strong will in finishing their tasks. This indicates that the implementation of contextual-based learning in Natural Science learning can improve students' creativity and the result is in accordance to studies [18] and [3]. Stated that students' creativity can be improved by various models of learning. One of which was contextual-based learning [19-21].

\section{CONCLUSION}

Based on the t-test, the significance value (2tailed) was 0.000 indicated that the value was lower than 0.05 , it can be concluded that Ho is rejected and $\mathrm{Ha}$ is accepted. The result indicated that the contextual-based learning in Natural Science can improve students' learning creativity.

\section{REFERENCES}

[1] Noviyanti, E. (2017). Pendekatan Saintifik dan Kontekstual dalam Pembelajaran Literasi Sains di Sekolah Dasar.In Prosiding Seminar Nasional (pp. 43-55).

[2] Anggraeni, A. Y., Wardani, S., \& Hidayah, A. N. (2020). Profil Peningkatan Kemampuan Literasi Kimia Siswa Melalui Pembelajaran Inkuiri Terbimbing Berbasis Kontekstual. Jurnal inovasi Pendidikan Kimia, 14(1), 2512-2523.

[3] Saragi, E., \& Simbolon, N. (2015). Penerapan Strategi Pembelajaran Contextual Teaching And Learning Dalam Meningkatkan Kreativitas Belajar Siswa Pada Pembelajaran Sains. INPAFI (Inovasi Pembelajaran Fisika), 3(1).

[4] Alamsyah, N. (2016). Penerapan pendekatan saintifik untuk meningkatkan kreativitas dan hasil belajar siswa dalam mata pelajaran IPA. JP (Jurnal Pendidikan): Teori dan Praktik, 1(1), 8296.

[5] Anggraeni, A. Y., Wardani, S., \& Hidayah, A. N. (2020). Profil Peningkatan Kemampuan Literasi Kimia Siswa Melalui Pembelajaran Inkuiri Terbimbing Berbasis Kontekstual. Jurnal inovasi Pendidikan Kimia, 14(1), 2512-2523.

[6] Siregar, H. (2020). Kreativitas siswa dalam mata pelajaran ipa. Journal Evaluation in Education (JEE), 1(1), 21-26.

[7] Effendi, M. (2016). Integrasi pembelajaran active learning dan internet-based learning dalam meningkatkan keaktifan dan kreativitas belajar. Nadwa, 7(2), 283-309.

[8] Septiana, R., Gani, R. A., \& Elizabeth, Y. (2019). Hubungan kreativitas belajar siswa dengan hasil belajar ilmu pengetahuan alam. PROCEEDINGSOPEN ACCESS JOURNAL, 1(01), 06-10.

[9] Manobe, S. M., \& Wardani, K. W. (2018). Peningkatan Kreativitas Belajar Ipa Menggunakan Model Problem Based Learning Pada Siswa Kelas 3 SD. Didaktika Dwija Indria, 6(8).

[10] Setiyorini, N. D. (2018). Pembelajaran Kontekstual IPA Melalui Outdoor Learning di SD Alam Ar-Ridho Semarang. Al-Mudarris: Journal Of Education, 1(1), 30-38.

[11] Farida, U., Agustini, F., \& Wakhyudin, H. (2017). Efektivitas Model Pembelajaran Scramble Berbasis Kontekstual Terhadap Kemampuan Berpikir Kritis IPS Siswa Kelas III SD Negeri Kebondalem 01 Batang. Jurnal Ilmiah Sekolah Dasar, 1(3), 192-199.

[12] Maknun, D. (2014). Penerapan pembelajaran kontekstual untuk meningkatkan literasi sains dan kualitas argumentasi siswa pondok pesantren daarul uluum pui majalengka pada diskusi sosiosaintifik IPA. Jurnal Tarbiyah, 21(1).

[13] Rati, N. W., Kusmaryatni, N., \& Rediani, N. (2017). Model pembelajaran berbasis proyek, kreativitas dan hasil belajar mahasiswa. JPI (Jurnal Pendidikan Indonesia), 6(1), 60-71.

[14] [14] Nugraha, A. R., Kristin, F., \& Anugraheni, I. (2018). Penerapan Model Pembelajaran Project Based Learning (Pjbl) Untuk Meningkatkan Kreativitas Dan Hasil Belajar Ipa Pada Siswa Kelas 5 Sd. KALAM CENDEKIA PGSD KEBUMEN, 6(4.1).

[15] Kusumawati, N. (2017). Penerapan Metode Active Learning Tipe Team Quiz Untuk Meningkatkan Keaktifan Bertanya Dan Kreatifitas Siswa Pada Mata Pelajaran Ipa Kelas V Sdn Ronowijayan Ponorogo. Jurnal Bidang Pendidikan Dasar, 1(2), 26-36.

[16] Kurniawan, A. D. (2013). Metode inkuiri terbimbing dalam pembuatan media pembelajaran biologi untuk meningkatkan pemahaman konsep dan kreativitas siswa SMP. Jurnal Pendidikan IPA Indonesia, 2(1).

[17] Setyowati, R., \& Purba, R. T. (2017). Peningkatan kreativitas siswa kelas 4 SD melalui model pembelajaran contextual teaching and learning (CTL). ELEMENTARY SCHOOL JOURNAL PGSD FIP UNIMED, 7(2), 293-307.

[18] Pamungkas, A., Subali, B., \& Linuwih, S. (2017). Implementasi model pembelajaran IPA berbasis kearifan lokal untuk meningkatkan kreativitas dan hasil belajar siswa. Jurnal Inovasi Pendidikan IPA, 3(2), 118-127.

[19] Ajwar, M., \& Yulianci, S. (2019). Penggunaan Open Ended untuk Meningkatkan Kreativitas Belajar Mahasiswa pada Mata Kuliah Konsep Dasar IPA. Jurnal Pendidikan Mipa, 9(1), 10-14.

[20] Busyairi, A., \& Sinaga, P. (2021). Pengembangan Instrumen Tes Model Ideation-Explanation Untuk 
J. Pijar MIPA, Vol. 16 No.5, November 2021: 659-663

Mengukur Kemampuan Berpikir Kreatif Dalam Pemecahan Masalah. Jurnal Pijar Mipa, 16(1), 57-63.

[21] Sari, F., Jufri, A. W., \& Sridana, S. (2017). Keefektifan Bahan Ajar IPA Berbasis Pendekatan SAVI untuk Meningkatkan Kreativitas Peserta Didik SMPN 3 Mataram. Jurnal Pijar MIPA, 12(2), 107-111. 